Research Note

\title{
Field Survey on Actual Conditions of Light Environment in Mid-scale Office Buildings in Japan
}

\author{
Etsuko MOCHIZUKI* and Katsuya KOIKE** \\ * Chiba Institute of Technology, Department of Architecture \& Civil Engineering \\ ** Environmental Planning \& Brain
}

Received January 7, 2010,Accepted July 20,2010

Paper originally published in Proceedings of the 6th Lux Pacifica, Bangkok, 2009

\begin{abstract}
Questionnaire and field measurements were conducted to identify the light environment and the occupants' visual comfort in mid-scale office buildings in Japan. The answers of the questionnaire were obtained from 389 workers in 77 different buildings. The results have identified that more than $60 \%$ of the occupants attended to their work at their own desk in over $80 \%$ of working hours. Also, it was identified that only $10 \%$ of the occupants used task lighting. On the other hand, $90 \%$ of the occupants answered that they always turned on the ceiling luminaires.

Field measurements were conducted in 9 different office buildings to identify the actual conditions of the environment around the windows. As results, it was identified that the percentage of the occupants who were dissatisfied with windows became higher in the cases where they could see nothing from the windows because they were covered by furmiture, documents and so on placed around them than when they had an outside view through the windows. Over $30 \%$ of the area within the windows was hidden by furniture or documents in more than $30 \%$ of the measured buildings.
\end{abstract}

KEYWORDS: office buildings, window, daylighting, arrangement of furmiture, questionnaire, field measurement

\section{Introduction}

It has been reported that energy consumption for interior lighting accounts for $21 \%$ of the total energy consumption in office buildings in Japan ${ }^{11}$. It is clear that using daylight as interior lighting contributes to energy savings in daytime. Recently in Japan, the number of the office buildings which introduce daylight into rooms by using some window systems which can be controlled automatically is increasing to reduce energy for interior lighting.

However, the number of the office buildings of small or middle scale is still large. In such buildings, it is hard to adopt automatic window systems and shading devices must be controlled manually. Once some shading devices such as Venetian blinds or window screens are pulled down, they are hardly pulled up regardless of the outside conditions ${ }^{2}$. That may prevent daylight entering from windows. Further, blocking the outside view and the light environment would be both against the occupants' visual comfort and against energy savings.

In this study, the questionnaire and field measurements in mid-scale office buildings were conducted to identify the actual conditions of the usage of the shading devices, the ceiling luminaires and the occupants' visual comfort.
2. Questionnaire on the occupants visual comfort in office Space

The questionnaire was conducted to identify the actual conditions of shading devices and ceiling luminaires in mid-scale office space in Japan.

\subsection{Method}

First, letters of request for cooperation in the survey on the light environment in office space were sent by mail to

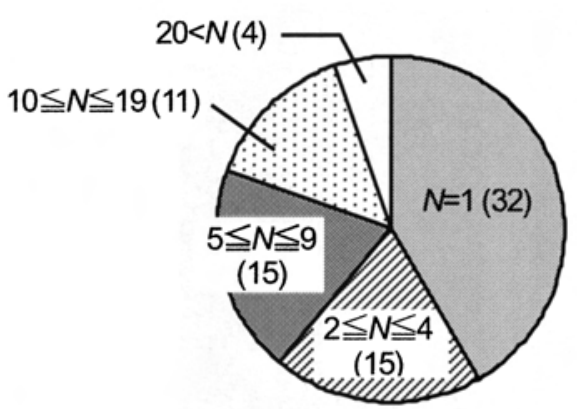

$N$ : Collected number of answers in each company (Total $=389$ ) Number in parenthesis: Number of companies (Total= 77)

Figure 1 Collected number of answers in each company 
441 randomly chosen companies in the Kanto region (Tokyo, Chiba and Saitama-prefecture) and 77 companies responded favourably. They also answered with the number of the employees who would answer the questions.

Next, sheets of the questionnaire were sent to each company by mail. Table 1 shows the contents of the questionnaire. Each question was asked to be answered on a clear day in August, 2007.

Figure 1 shows the collected number of answers, namely the number of the employees who answered the question, in each company. All 389 answers were collated from 77 different companies.

Table 1 Contents of the questionnaire

\begin{tabular}{|c|c|c|}
\hline & Question & Scale \\
\hline Q1 & \multicolumn{2}{|c|}{ Please tell me about the light environment around your desk. } \\
\hline Q1-1 & How is the brightness on your desk? & Very bright/ Bright/ Neutral/ Dark/ Very dark \\
\hline Q1-2 & $\begin{array}{l}\text { Do you feel uneasy about the lack in uniformity of } \\
\text { brightness on your desk? }\end{array}$ & Yes/ No \\
\hline Q1-3 & $\begin{array}{l}\text { Do you feel uneasy about the reflection on your } \\
\text { desk? }\end{array}$ & Yes/ No \\
\hline Q1-4 & $\begin{array}{l}\text { Do you feel uneasy about the reflection on VDT } \\
\text { display? }\end{array}$ & Yes/ No \\
\hline Q1-5 & Do you have task lighting? & Yes/ No \\
\hline Q1-6 & $\begin{array}{l}\text { How often do you use the task lighting (if you } \\
\text { have it)? }\end{array}$ & Always/ Often/ Sometimes/ Never \\
\hline Q1-7 & How often do you use the ceiling illumination? & Always/ Often/ Sometimes/ Never \\
\hline Q1-8 & Do you have partitions around your desk? & Yes/ No \\
\hline Q1-9 & $\begin{array}{l}\text { What are the good/ bad points caused by the } \\
\text { partitions (if you have them)? }\end{array}$ & $\begin{array}{l}\text { Good for isolating myself from the others/ Can concentrate on } \\
\text { work/ Feel calm/ Feel loneliness/ Dark/ Hard to communicate with } \\
\text { the others/ Feel closed-in/ Feel uneasy about the other's eyes }\end{array}$ \\
\hline Q1-10 & $\begin{array}{l}\text { What are the good/ bad points caused by the } \\
\text { absence of partitions, if you don't have them? }\end{array}$ & $\begin{array}{l}\text { Good to be able to look around/ Can concentrate on work/ Feel } \\
\text { calm/ Don't feel loneliness/ Bright/ Easy to communicate with the } \\
\text { other/ Feel openness/ Feel uneasy about the other's eye }\end{array}$ \\
\hline Q1-11 & How long do you work a day? & $\begin{array}{l}\text { I work about } \_ \text {hours a day on average. } \\
\text { I work about } \_ \text {hours at my desk a day on average. }\end{array}$ \\
\hline Q1-12 & How are the things on your desk kept? & $\begin{array}{l}\text { In good order/ In disorder/ Narrow for working/ Large enough for } \\
\text { working }\end{array}$ \\
\hline Q1-13 & $\begin{array}{l}\text { Are you satisfied with the light environment } \\
\text { around your desk? }\end{array}$ & Very satisfied/ Satisfied/ Neutral/ Dissatisfied/Very dissatisfied \\
\hline Q2 & Please tell me about the windows in your office spa & \\
\hline Q2-1 & $\begin{array}{l}\text { What can you see from the window nearest to } \\
\text { your seat in the case when the window is not } \\
\text { closed over by any shading devices? }\end{array}$ & $\begin{array}{l}\text { Only buildings/ Only sky/ Both buildings and sky/ Nothing/ Other, } \\
\text { e. g. Gardens, park, trees etc... }\end{array}$ \\
\hline Q2-2 & $\begin{array}{l}\text { How often do you use the shading devices such } \\
\text { as Venetian blinds? }\end{array}$ & Always/Often/ Sometimes/Never \\
\hline Q2-3 & $\begin{array}{l}\text { Do you feel uneasy about the shadow of your own } \\
\text { hand? }\end{array}$ & Yes/ No \\
\hline Q2-4 & $\begin{array}{l}\text { Is it easy to see the face of a person with whom } \\
\text { you are talking with the windows at your back? }\end{array}$ & Yes/ No \\
\hline Q2-5 & $\begin{array}{l}\text { Are you satisfied with the windows near to your } \\
\text { seat? }\end{array}$ & Very satisfied/ Satisfied/ Neutral/ Dissatisfied/ Very dissatisfied \\
\hline Q3 & Please tell me about the light environment in your o & fice space. \\
\hline Q3-1 & How is the brightness in your whole workspace? & Very bright/ Bright/ Neutral/ Dark/ Very dark \\
\hline Q3-2 & $\begin{array}{l}\text { How do you feel about the atmosphere in your } \\
\text { workspace? }\end{array}$ & $\begin{array}{l}\text { Feel calm/ Bursting with energy/ Feel openness/ Gloomy/ Feel } \\
\text { oppressive/ Feel cramped/ Feel closed-in }\end{array}$ \\
\hline Q3-3 & $\begin{array}{l}\text { Are you satisfied with the light environment in } \\
\text { your workspace? }\end{array}$ & Very satisfied/ Satisfied/ Neutral/ Dissatisfied/Very dissatisfied \\
\hline
\end{tabular}




\subsection{Results}

The results of the questionnaire were analyzed all together because the number of answers in each company varied widely, as shown in Figure 1.

\section{1) Actual conditions of the usage of the workspace}

Figure 2 shows the frequency of working hours a day on average. It can be seen that more than half of the respondents work over 9 hours a day on average. Also it can be seen that about half of the respondents work over 8 hours at their own desks. Table 2 shows the frequency of the ratio of the hours when the respondents work at their own desks in a day's working hours. It was identified that more than $60 \%$ of the respondents work at their own desks over $80 \%$ of a day's working hours.

Table 3 shows the actual conditions of the things on the desks. There were lots of things on the desks of over half of the respondents and they felt the desks were narrow for working.

\section{2) Actual conditions of the usage of the lighting}

Figure 3 shows the percentage of the respondents who had task lighting and the distribution of the frequency of the usage of it. It was identified that about $97 \%$ of the respondents did not use task lighting even though they had it available.

Table 4 shows the distribution of the frequency of the usage of ceiling illumination. It can be seen that over $91 \%$ of the respondents always turned on the ceiling luminaires.

\section{3) Effects of the partitions around the desk}

Figure 4 shows the evaluation of their workspace with/ without partitions around their desks. The number who had partitions was 69 and those who did not have partitions was 320 . It was identified that most of the respondents did not have partitions around their desks. The striking differences between the answers by those who had partitions and by those who did not concerned concentration, calm, communication and openness. It was identified that the occupants could concentrate on their work and could feel calm by using partitions. On the other hand, it was easier for the occupants who did not have partitions to communicate with the others and to feel openness -qualities unavailable to those who had partitions.

\section{4) Evaluation of the light environment}

Table 5 shows the results of the answers to Q2-1. It was identified that about $25 \%$ of the respondents could not see anything through the windows nearest to their seats. It could be supposed that they were sitting with the windows at their back or the windows were blocked by furniture, books, documents and so on.

Table 6 shows the distribution of the frequency of the usage of the shading devices over the windows. It was identified that the shading devices were always closed over the windows in the workspace of $34.2 \%$ of the

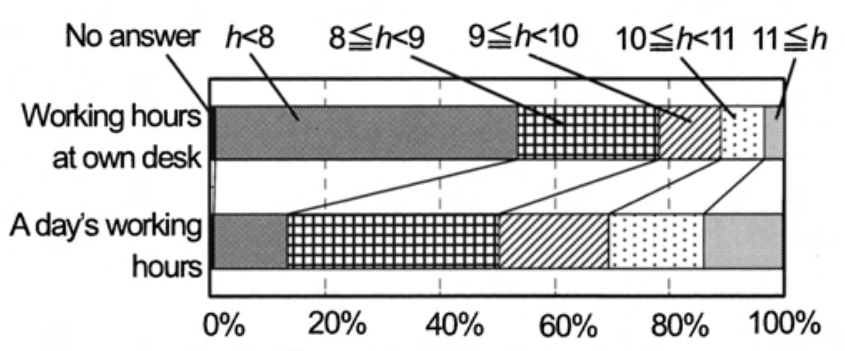

Figure 2 Working hours a day on average (Q1-11)

Table 2 Ratio of working hours at own desk to a day's working hours

\begin{tabular}{|c|c|c|}
\hline$r=\frac{\text { Working hours at own desk }}{\text { Aday's working hours }}$ & Percentage & $\begin{array}{c}\text { Cumulative } \\
\text { percentage }\end{array}$ \\
\hline No answer & $1.0 \%$ & - \\
\hline$r<50 \%$ & $5.1 \%$ & $5.1 \%$ \\
\hline $50 \% \leqq r<60 \%$ & $4.4 \%$ & $9.5 \%$ \\
\hline $60 \% \leqq r<70 \%$ & $7.7 \%$ & $17.2 \%$ \\
\hline $70 \% \leqq r<80 \%$ & $14.7 \%$ & $31.9 \%$ \\
\hline $80 \% \leqq r<90 \%$ & $28.0 \%$ & $59.9 \%$ \\
\hline $90 \% \leqq r$ & $39.1 \%$ & $99.0 \%$ \\
\hline
\end{tabular}

Table 3 Number of answers to Q1-12 (Multiple-choice was available)

\begin{tabular}{|c|c|c|c|}
\cline { 3 - 4 } \multicolumn{2}{c|}{} & Narrow for working & Large for working \\
\hline In good order & 126 & 18 & 27 \\
\hline In disorder & 174 & 87 & 13 \\
\hline Sum & 300 & 105 & 40 \\
\hline
\end{tabular}

Q1-5 Do you have task lighting?

Q1-6 How often do you use the task lighting?

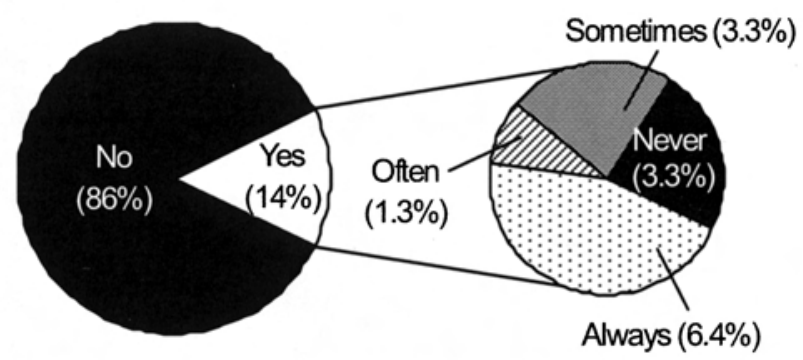

Figure 3 Frequency of the usage of the task lighting (Q1-5, Q1-6)

Table 4 Frequency of the usage of the celing illumination (Q1-7)

\begin{tabular}{|c|c|}
\hline $\begin{array}{c}\text { Frequency of the usage of } \\
\text { ceiling illumination }\end{array}$ & Percentage \\
\hline Always & $91.3 \%$ \\
\hline Often & $4.6 \%$ \\
\hline Sometimes & $1.5 \%$ \\
\hline Never & $1.8 \%$ \\
\hline No answer & $0.8 \%$ \\
\hline Sum & $100.0 \%$ \\
\hline
\end{tabular}




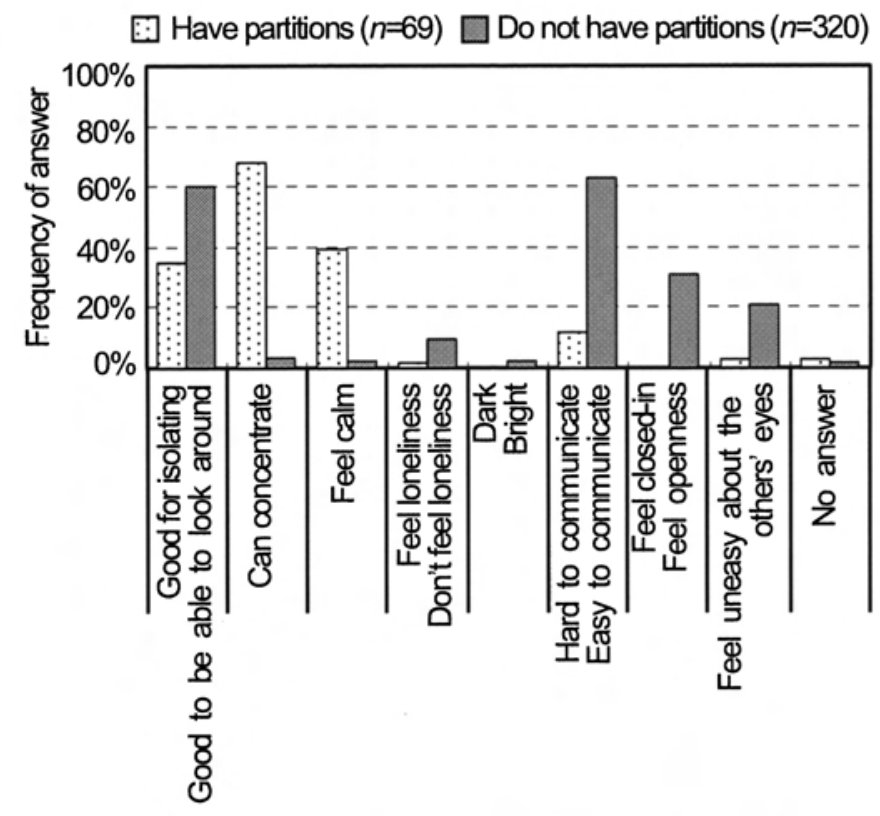

Table 5 View from the nearest window (Q2-1)

\begin{tabular}{|c|c|}
\hline What can be seen from the nearest window & Percentage \\
\hline Only buildings & $28.0 \%$ \\
\hline Only sky & $5.1 \%$ \\
\hline Both buildings and sky & $39.9 \%$ \\
\hline Nothing & $25.4 \%$ \\
\hline No answer & $1.5 \%$ \\
\hline Sum & $100.0 \%$ \\
\hline
\end{tabular}

Table 6 Frequency of the usage of the shading devices (Q2-2)

\begin{tabular}{|c|c|}
\hline Frequency of the usage of shading devices & Percentage \\
\hline Always & $34.2 \%$ \\
\hline Often & $21.3 \%$ \\
\hline Sometimes & $19.3 \%$ \\
\hline Never & $23.1 \%$ \\
\hline No answer & $2.1 \%$ \\
\hline Sum & $100.0 \%$ \\
\hline
\end{tabular}

Figure 4 Evaluation of workspace with/ without partitions (Q1-9, Q1-10, Multiple-choice was available)

Table 7 Cross tabulation between visible area of the outside view through the nearest window and satisfaction level with windows (Q2-5)

\begin{tabular}{|c|c|c|c|c|c|c|c|c|}
\hline & & \multicolumn{7}{|c|}{ Visible component through the nearest window } \\
\hline & & Only buildings & Only sky & Buildings \& sky & Nothing & & No answer & Sum \\
\hline \multirow{7}{*}{ 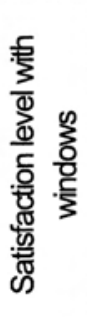 } & Very satisfied & $1.0 \%$ & $0.3 \%$ & $2.0 \%$ & $0.0 \%$ & & $0.0 \%$ & $3.3 \%$ \\
\hline & Satisfied & $4.9 \%$ & $1.0 \%$ & $13.4 \%$ & $1.8 \%$ & & $0.0 \%$ & $21.1 \%$ \\
\hline & Neutral & $18.0 \%$ & $2.8 \%$ & $20.8 \%$ & $15.7 \%$ & & $0.3 \%$ & $57.6 \%$ \\
\hline & Dissatisfied & $2.8 \%$ & $1.0 \%$ & $3.3 \%$ & $4.1 \%$ & \multirow{4}{*}{$\begin{array}{c}31.4 \\
\%\end{array}$} & $0.0 \%$ & $11.2 \%$ \\
\hline & Very dissatisfied & $1.3 \%$ & $0.0 \%$ & $0.3 \%$ & $3.9 \%$ & & $0.0 \%$ & $5.5 \%$ \\
\hline & No answer & $0.0 \%$ & $0.0 \%$ & $0.0 \%$ & $0.0 \%$ & & $1.3 \%$ & $1.3 \%$ \\
\hline & Sum & $28.0 \%$ & $5.1 \%$ & $49.9 \%$ & $25.5 \%$ & & $1.6 \%$ & $100 \%$ \\
\hline
\end{tabular}

respondents.

Table 7 shows the results of the cross tabulation between visible components of the outside view through the window nearest to the respondent's seat and the satisfaction level with windows. It was identified that the respondents who were dissatisfied with windows comprised about $31.4 \%(=(4.1 \%+3.9 \%) / 25.5 \%)$ of those who could see nothing through the windows. That percentage was higher than that found among the other answers.

For the phenomena caused by the directional light from windows such as shadow of their own hand (Q2-3) or silhouette phenomenon (Q2-4), over $80 \%$ of the respondents answered that they did not feel uneasy about the shadow of their own hand or the fact that they could see the faces of those with whom they were talking with. Concerning reflection, the percentage of the respondents who felt uneasy about the reflection on their own desk was only $18 \%(\mathrm{Q} 1-3)$. On the other hand, the percentage of

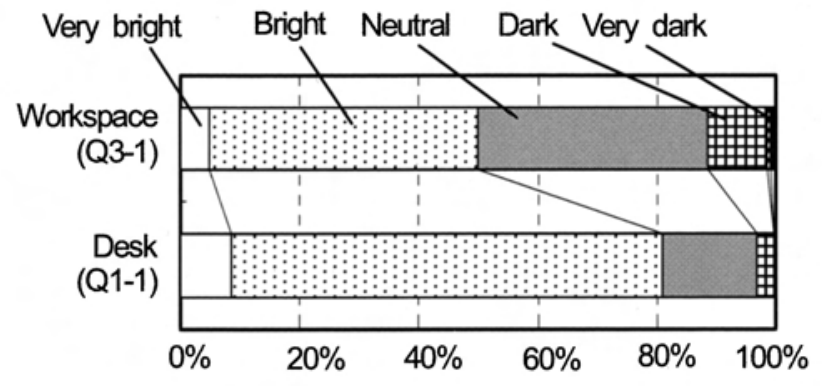

Figure 5 Brightness on the desk and whole workspace (Q1-1, Q3-1)

the respondents who felt uneasy about the reflection on VDT display was much higher than that on the desks, about 38\% (Q1-4).

Figure 5 shows the frequency of brightness sensation of each respondent's desk and that of the whole workspace. It can be seen that more than $80 \%$ of the respondents evaluated their desks to be rather bright and about half of the respondents evaluated that the workspace was bright. 
The percentage of the respondents who used task lighting was only $15 \%$ among those who judged the brightness of their desks higher than that of the whole workspace. Further investigation should identify the reasons why the brightness sensation of the whole workspace was lower than that of the desk. It was also identified that over $80 \%$ of the respondents did not feel uneasy about the lack in uniformity of brightness on their desks.

Figure 6 shows the frequency of the satisfaction level with the environment around each respondent's desk and that with the environment in each respondent's workspace. Both percentages of the respondents who were dissatisfied with the environment were less than $10 \%$.

\section{Field measurements on the light environment in office} space

From the results of the questionnaire on 389 office workers of 77 different companies, about half of the respondents evaluated the brightness of their own desks higher than that of their whole workspace. However, the percentage who used task lighting was less than $10 \%$. It was also identified that the percentage of those dissatisfied with windows in the case when they could not see windows or an outside view through windows was higher than in the case where they could.

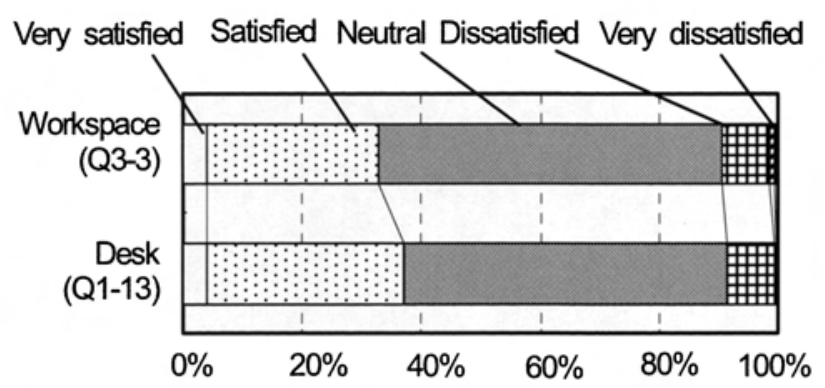

Figure 6 Satisfaction level with the environment around the desk and that in the workspace (Q1-13, Q3-3)

Table 8 Outine of the measured office buildings

\begin{tabular}{|c|c|c|c|c|c|c|c|c|}
\hline & Location & Completed & $\begin{array}{l}\text { Measured } \\
\text { floor }\end{array}$ & $\begin{array}{c}\text { Area of the } \\
\text { measured } \\
\text { space }\end{array}$ & $\begin{array}{l}\text { Shading } \\
\text { device }\end{array}$ & $\begin{array}{l}\text { Task } \\
\text { lighting }\end{array}$ & $\begin{array}{l}\text { Number of workers in } \\
\text { the measured space }\end{array}$ & $\begin{array}{c}\text { Appearance of the } \\
\text { space }\end{array}$ \\
\hline A & Tokyo & 2005 & $2 F$ & $136 \mathrm{~m}^{2}$ & $\begin{array}{l}\text { Venetian blind } \\
\text { (manual) }\end{array}$ & No & 45 & \\
\hline B & Tokyo & 2006 & $13 \mathrm{~F}$ & $525 \mathrm{~m}^{2}$ & $\begin{array}{l}\text { Venetian blind } \\
\text { (manual) }\end{array}$ & Yes & 54 & \\
\hline C & Chiba & 1991 & $4 \mathrm{~F}$ & $957 \mathrm{~m}^{2}$ & $\begin{array}{l}\text { Venetian blind } \\
\text { (manual) }\end{array}$ & No & 100 & \\
\hline D & Tokyo & 1993 & $15 \mathrm{~F}$ & $971 \mathrm{~m}^{2}$ & $\begin{array}{l}\text { Venetian blind } \\
\text { (manual) }\end{array}$ & Yes & 89 & \\
\hline $\mathrm{E}$ & Chiba & 1991 & $2 F$ & $104 \mathrm{~m}^{2}$ & $\begin{array}{l}\text { Venetian blind } \\
\text { (manual) }\end{array}$ & No & 21 & \\
\hline$F$ & Tokyo & 1987 & B1F & $87.7 \mathrm{~m}^{2}$ & $\begin{array}{l}\text { Venetian blind } \\
\text { (manual) }\end{array}$ & Yes & 12 & \\
\hline G & Tokyo & 1986 & $3 F$ & $138 \mathrm{~m}^{2}$ & $\begin{array}{l}\text { Venetian blind } \\
\text { (manual) }\end{array}$ & No & 24 & \\
\hline $\mathrm{H}$ & Tokyo & 1975 & $4 \mathrm{~F}$ & $449 m^{2}$ & $\begin{array}{l}\text { Venetian blind } \\
\text { (manual) }\end{array}$ & No & 30 & \\
\hline 1 & Chiba & 1980 & $1 \mathrm{~F}$ & $294 \mathrm{~m}^{2}$ & $\begin{array}{l}\text { Venetian blind } \\
\text { (manual) }\end{array}$ & No & 25 & \\
\hline
\end{tabular}


In this paper, field measurements in mid-scale office space were conducted to identify the actual conditions of the environment around the windows and the effects of windows on the light environment in the workspace.

\subsection{Outline of the measured buildings}

The measurements were conducted in 9 office buildings where the questionnaires were also conducted. Table 8 shows the outline of the measured office buildings. All of them had Venetian blinds which could be controlled manually and they were usually pulled down in most cases as shown in Table 8. Especially in the cases of B, C, F, G, H and I, it could be seen that a mountain of documents was piled in front of windows; or, furniture obstructed the view from windows.

\subsection{Method}

The measurement of each building was conducted on a clear day in September or October, 2007. The purpose of the measurement was to identify the actual conditions of the environment around the windows. The percentage of the area within windows that was blocked by furniture, books, documents and so on was measured by CCD camera system (CANON EOS 5D with fish-eye lens of equisolidangle projection) at several different points according to the distance from the window. Also, illuminance on the desk was measured at intervals of $2 \mathrm{~m}$ by illuminance meter (KONICA-MINOLTA T-10M). All measurements were conducted three times a day $-10: 00$, 12:30 and 15:00 under usual states.

\subsection{Results}

\section{1) Illuminance on the desk}

Average illuminance on the desk in each building is shown in Figure 7. In the buildings B and E, average illuminance on the desk measured at 12:30 was lower than $500 \mathrm{~lx}$, the JIS recommended level for VDT tasks ${ }^{3)}$, because ceiling luminaires were turned off during the noon recess. In the other cases, average illuminance on the desk in each building satisfied the JIS recommended level for VDT tasks.

2) Percentage of area covered by furniture, documents and Venetian blinds within windows

The percentage of the area within windows that was covered by furniture etc was estimated by Equation (1) and Figure 8. Both $N_{v}$ and $N_{t}$ were obtained from the images taken by CCD camera system with fish eye lens of equisolidangle projection.

$$
c=1-\frac{\omega_{v}}{\omega}=1-\frac{N_{v} / N_{t} \times 2 \pi}{\omega}
$$

$c$ : Percentage of the area covered by furniture, documents and Venetian blinds within every window in the workspace

$\omega_{v}$ : Solid angle of the visible area within every window in the workspace from the measurement point

$\omega$ : Solid angle of every window in the workspace from the measurement point

$N_{v}$ : Number of pixels of visible area within every window in the workspace that was not covered by furniture, documents and Venetian blinds

\section{$N_{t}$ : Total number of pixels of the image}

Figure 9 shows the relationship between the solid angle of every window in the workspace and that of the visible area within every window in the workspace measured from different points in each building. It can be seen that the solid angle of the visible area within the windows in $\mathrm{F}$ $(\boldsymbol{O}), \mathrm{G}(\boldsymbol{\Delta})$ and I $(\bullet)$ were much lower than those of the windows. In the other buildings, the difference between the solid angle of the visible area within the windows and

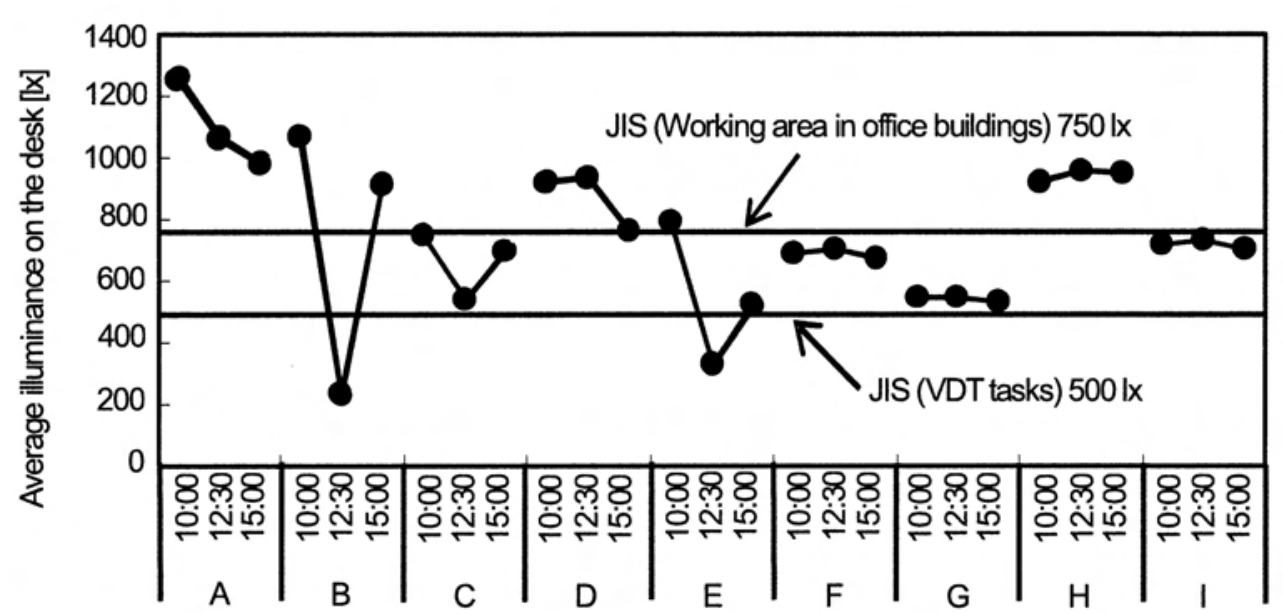

Figure 7 Average illuminance on the desk in each building

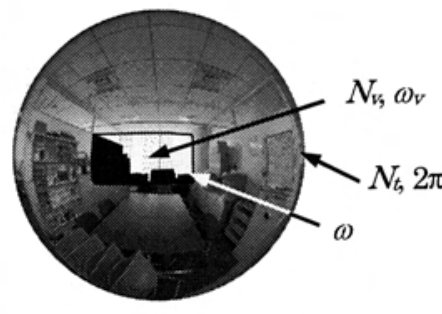

Figure 8 Estimation of the percentage of the covered area within window by furniture, documents and Venetian blinds 
that of the windows was rather small.

Figure 10 shows the frequency of the percentage of the area within windows in the workspace that was covered by furniture, documents and Venetian blinds, calculated by Equation (1). It could be seen that more than $30 \%$ of the area within the windows was covered by furniture or documents in about $30 \%$ of measured buildings. Moreover, more than half of the area within the window was covered by documents, furniture and Venetian blinds in over $40 \%$ of measured buildings.

\section{Discussion}

The relationship between the results of the questionnaire and that of the field measurement on the environment around the windows was examined.

Figure 11 shows the average of brightness sensation of the desk, that of the whole workspace and the frequency of the visible components of the outside view through the window in each measured building. The numbers in parenthesis under the names of the building mean the number of the answers obtained in the questionnaire. It can be seen that the percentages of the respondents in $\mathrm{F}$ and $\mathrm{H}$ who could see nothing through the windows accounted for over $50 \%$. Also, it can be seen that averages of brightness sensation of the whole workspace in F, G and I were much lower than those of the desk. On the other hand, both the brightness sensation of the desk and that of the whole workspace were almost the same in all buildings except for $\mathrm{F}, \mathrm{G}$ and I.

Table 9 shows the results of the cross tabulation between the frequency of the use of ceiling illumination and that of the shading devices. The upper values in each cell mean the results of the buildings except for F, G and I. On the other hand, the lower values in each cell mean the results of F, G and I. Over $90 \%$ of the respondents in each group answered they always turned on the ceiling luminaires. For the use of shading devices, it was found that the percentage of the respondents in $\mathrm{F}, \mathrm{G}$ and $\mathrm{I}$ who answered they never used the shading devices was higher than that in the other buildings. It could be supposed that the windows in F, G and I were covered by furniture, documents and so on, rather than by the shading devices.

Average illuminance on the desk in each building was kept higher than $500 \mathrm{~lx}$ of the JIS recommended level for VDT tasks owing to the ceiling luminaires, furniture or documents being put away from the area around the windows. Doing this will make the occupants more satisfied with windows by retaining the outside view. It will also enhance energy conservation.

\section{Conclusions}

The questionnaire was carried out in 77 different companies and 389 answers were obtained. Field measurements in 9 different office buildings were

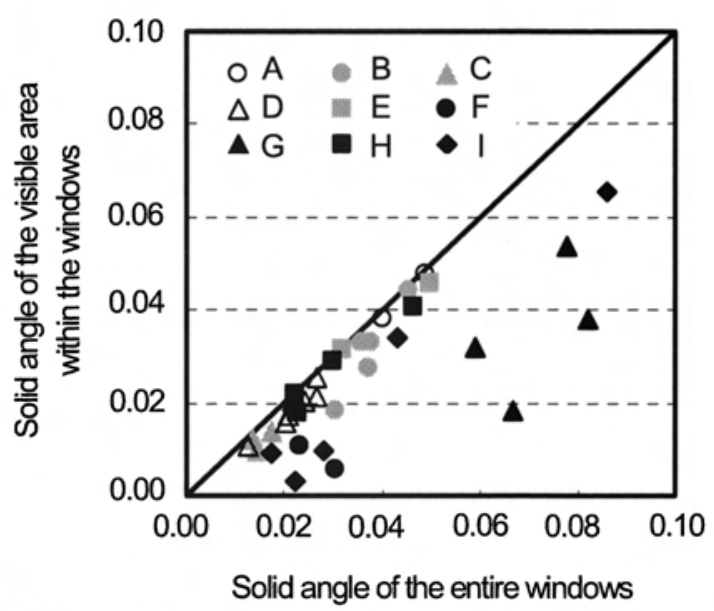

Figure 9 Relationship between the solid angle of the windows and that of the visible area within the windows in each building

Covered by fumiture \& documents

$\square$ Covered by fumiture, documents \& Venetian blinds

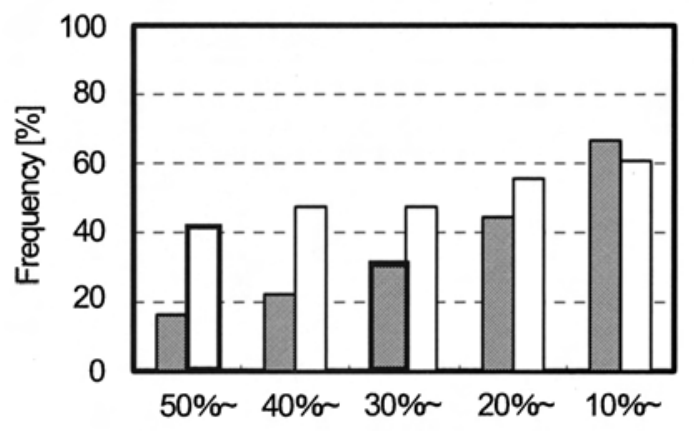

Percentage of covered area within windows $c$

Figure 10 Percentage of the area that was covered by fumiture, documents and Venetian blinds within windows

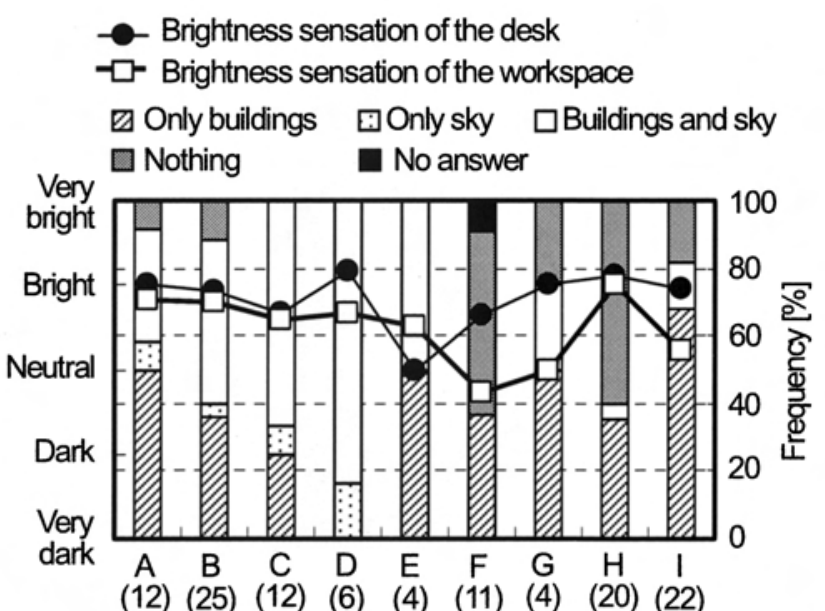

Figure 11 Average of brightness sensation of desk and that of the workspace and visible component through the nearest window in each building 
conducted to identify the actual conditions of the environment around the windows. The results were shown as follows.

1) More than $60 \%$ of the occupants attended to their work at their own desks in over $80 \%$ of working hours.

2) The percentage of the occupants who used task lighting was only $10 \%$. This result was higher than that investigated in 1992 by the Illuminating Engineering Institute of Japan (the percentage of the office buildings that adopted task and ambient lighting was $5 \%$ among 208 office buildings) ${ }^{4)}$.

3) Over $90 \%$ of the occupants answered that they always turned on ceiling luminaires.

4) The percentage of the occupants who were dissatisfied with windows in the cases where they could not see an outside view through windows became higher than when they had an outside view through windows.

5) The main reason why the occupants could not see the outside view through windows was the proliferation of furniture or documents placed around the windows.

The target area of this paper was limited to Kanto region, so that more data in a wider area is required to get general results. Moreover, the possibility for turning off the ceiling luminaires because of the removal of furniture or documents allowing more light to enter should be analyzed from the point of view of energy conservation by using natural light.

\section{Acknowledgements}

The authors would like to show special thanks to Miss. Kyoko Maie, at the time a student of Chiba Institute of Technology for her cooperation in the field measurements.

\section{References}

(1) Japan Luminaires Association, Recommendation for renewal of luminaires, p. 3 (2009) (in Japanese).

(2) Tokura, M., Tamura, H., Iwata, T., Yamazaki, Y. and Nakamura, Y.: A field measurement using a hexahedral illuminance meter of luminous environment in an actual bilateral lighting office, Proceedings of annual conference of IEIJ, pp. 171172 (2001) (in Japanese).

(3) JIS Z 9110: 1979, Recommended levels of illumination (1979) (in Japanese).

(4) Report of research \& investigation committee on actual conditions of lighting in intelligent office buildings, Tokyo branch of the illuminating engineering institute of Japan, (1993) (in Japanese).
Table 9 Cross tabulation between the use of ceiling illumination and that of shading devices

\begin{tabular}{|c|c|c|c|c|c|c|}
\hline & \multicolumn{5}{|c|}{ Use of ceiling illumination [\%] } \\
\hline & & Always & Often & Sometimes & Never & Sum \\
\hline \multirow{10}{*}{ 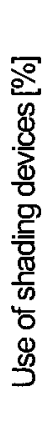 } & \multirow{2}{*}{ Always } & 28.5 & 1.6 & 0.0 & 0.0 & 30.1 \\
\hline & & 17.0 & 0.0 & 0.0 & 0.0 & 17.0 \\
\hline & \multirow{2}{*}{ Often } & 31.8 & 3.2 & 0.0 & 0.0 & 35.0 \\
\hline & & 9.4 & 1.9 & 0.0 & 0.0 & 11.3 \\
\hline & \multirow{2}{*}{ Sometimes } & 17.4 & 0.0 & 0.0 & 0.0 & 17.4 \\
\hline & & 15.1 & 1.9 & 0.0 & 0.0 & 17.0 \\
\hline & \multirow{2}{*}{ Never } & 14.3 & 1.6 & 0.0 & 1.6 & 17.5 \\
\hline & & 49.0 & 1.9 & 1.9 & 1.9 & 54.7 \\
\hline & \multirow{2}{*}{ Sum } & 92.0 & 6.4 & 0.0 & 1.6 & 100.0 \\
\hline & & 90.5 & 5.7 & 1.9 & 1.9 & 100.0 \\
\hline
\end{tabular}

except for $F, G$ and $I(N=79)$ $F, G$ and $I(N=37)$ 